\title{
Microbial decomposition of phyto- and zooplankton in seawater. I. Changes in organic matter
}

\author{
K. Fukami, U. Simidu and N. Taga \\ Ocean Research Institute, University of Tokyo, Nakano, Tokyo 164, Japan
}

\begin{abstract}
Fluctuations in the concentrations of various types of organic matter during decomposition of the diatom Skeletonema costatum (Grev.) Cleve and the copepod Tigriopus japonicus Mori were investigated under laboratory conditions. During decomposition of the diatom, concentration of particulate protein increased for the first few days in spite of continual decrease in particulate organic carbon (POC). During decomposition of the copepod, on the other hand, concentration of particulate protein decreased parallel to that of POC. The decrease of POC in the copepod body was rather slow, presumably because of the chitinous exoskeleton. These results suggest that detritus, especially that derived from phytoplankton, becomes nitrogen-rich during early stages of decomposition due to growth of bacteria on the detritus.
\end{abstract}

\section{INTRODUCTION}

Marine heterotrophic bacteria play an important role in the decomposition of particulate organic matter (POM) derived from higher organisms. Bacteria growing on the degrading organic matter then serve as food for bacteriovores such as microflagellates and ciliates (Fenchel, 1980, 1982). Thus, it is of importance to investigate POM decomposition by bacteria.

In the field, phytoplankters grow and excrete organic materials which (1) serve as substrate for bacteria and (2) react as bactericides (Kogure et al., 1979). Also bacteriovores decrease the number of bacteria. Hence it is difficult to investigate bacterial processes separately from the various other factors which complicate the process of decomposition (Fukami et al., 1983). While there have been a number of reports on phytoplankton decomposition in the laboratory (e.g. Grill and Richards, 1964; Otsuki and Hanya, 1972; Miyoshi, 1976; Fukami et al., 1981), only a few papers have been published on the decomposition of zooplankton (Harding, 1973).

In this study, conducted under simple laboratory conditions, detrital organic matter derived from plankton is decomposed exclusively by heterotrophic bacteria; we describe the changes in organic matter du- ring degradation of phytoplankton and compare them with decomposition of zooplankton. Changes in the bacterial community during decomposition are described in the following paper (Fukami et al., 1985).

\section{MATERIALS AND METHODS}

Preparation of plankton samples. For the phytoplankton decomposition experiment, an axenic culture of Skeletonema costatum (Grev.) Cleve was used. Cells of $S$. costatum in the exponential growth phase were collected by centrifugation and washed 3 times with sterile $3 \% \mathrm{NaCl}$ solution; this concentrated cell suspension was placed in the dark at $0^{\circ} \mathrm{C}$ (the procedure is described in detail by Fukami et al., 1981). The resulting cell suspension was resuspended in $10 \mathrm{l}$ of sterile filtered seawater. In the decomposition experiment for zooplankton, the marine copepod Tigriopus japonicus Mori was used. Individual $T$. japonicus were collected from a tidal pool in Aburatsubo Inlet, Japan, in April 1981. After being separated by a $690 \mu \mathrm{m}$ and/or $94 \mu \mathrm{m}$ nylon net, the plankters were washed with filtered seawater, frozen to death at $-20^{\circ} \mathrm{C}$, and then used for the experiment. This suspension was also resuspended in 101 of sterile seawater. Decomposition experiments 
were carried out after inoculation of these plankton suspensions with natural seawater containing microorganisms.

Inoculation of microorganisms. Seawater samples for inoculation were taken aseptically from surface water of Aburatsubo Inlet on September 15, 1981 for the experiment with Skeletonema costatum, and on May 18, 1981 for the experiment with Tigriopus japonicus. To prepare a sample containing mainly 'free-living' bacteria, and to eliminate heterotrophic microflagellates and other protozoans, the seawater sample was filtered through a sterile Nuclepore filter (pore size $2.0 \mu \mathrm{m}$ ); the filtrate is referred to as 'freeliving sample'. The $2.0 \mu \mathrm{m}$ Nuclepore filter was homogenized in a blender with sterile seawater and then refiltered through $2.0 \mu \mathrm{m}$ Nuclepore filter. This filtrate is referred to as 'attached sample'. Five $\mathrm{ml}$ of each sample ('attached sample' and 'free-living sample') were added to the plankton suspensions at the start of the experiment.

Incubation and subsampling. Decomposition experiments were conducted in the dark at $20^{\circ} \mathrm{C}$. The sample was stirred slowly with a magnetic stirrer (Fig. 1). At measured time intervals, after thorough stirring, aliquots of the sample were withdrawn with a siphon, then submitted to chemical and microbiological analyses.

Determination of organic matter. Concentrations of particulate organic carbon (POC), particulate organic nitrogen (PON), dissolved organic carbon (DOC) and particulate protein were determined. The methods were the same as those described previously (Fukami et al., 1981). Concentration of particulate protein was determined by the method of Iwamura et al. (1970). The filter on which particulate materials were collected was cut into strips and added to $5 \mathrm{ml}$ of $1 \mathrm{~N}$ $\mathrm{NaOH}$ solution, incubated at $37^{\circ} \mathrm{C}$ for $18 \mathrm{~h}$. In the case of Tigriopus japonicus, all plankters on the filter were ground with a pestle in $1 \mathrm{~N} \mathrm{NaOH}$ and incubated at $37^{\circ} \mathrm{C}$ for $18 \mathrm{~h}$. The incubated samples were filtered through a Whatman No. 44 paper filter. The amount of protein in the filtrate was then determined spectrophotometrically by the method of Lowry et al. (1951). The resulting values are presented as the amount of carbon (particulate protein carbon, PPC), by multiplying the values of protein by 0.475 .

\section{RESULTS}

Fluctuations of organic matter concentrations during degradation of Skeletonema costatum are shown in Fig. 2 and 3. The initial amount of POC derived from $S$. costatum was about $2.1 \mathrm{mg} \mathrm{Cl}^{-1}$. The concentration of POC decreased continuously up to Day 21. The POC : PON ratio decreased on the first day and then remained almost constant, being between 5 to 6 up to Day 20. The concentration of DOC increased on the first day, and then decreased rapidly on the 3rd day (Fig. 2). The concentration of particulate protein, in contrast to the continual decrease of POC, increased during the first $3 \mathrm{~d}$ and then decreased (Fig. 3). Along with this, the proportion of protein carbon to POC (PPC : POC) increased until Day 8. To see if these results were observed generally in the decomposition of phytoplankton, fresh cell material of $S$. costatum was added to the system on Day 23. The results (Fig. 2 and 3) show that similar processes were again observed after Day 24.

Fig. 4 and 5 show the results of the experiment with Tigriopus japonicus. The initial amount of POC derived from $T$. japonicus was about $10 \mathrm{mg} \mathrm{Cl}^{-1}$; that of DOC, $4.4 \mathrm{mg} \mathrm{C} \mathrm{l}^{-1}$. The POC concentration decreased rapidly during the first week. The POC: PON ratio also decreased for the first few days, then increased slightly; however, the change was not great and the ratio had a nearly constant value of ca. 5. DOC, in contrast to the experiment with phytoplankton, did

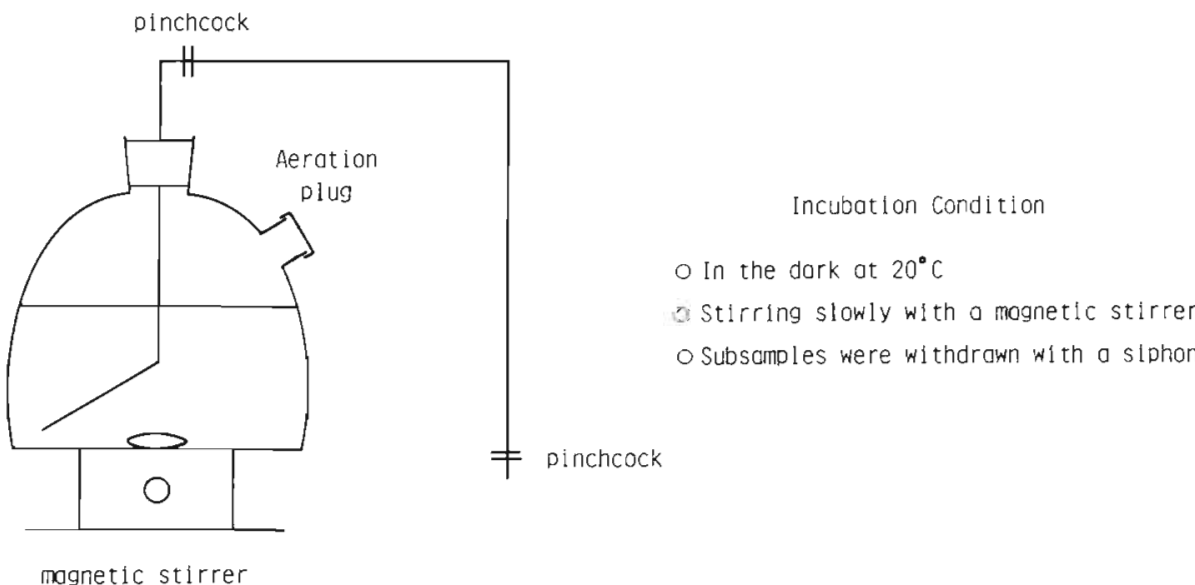

Fig. 1. Apparatus and incubation conditions used for plankton decomposition experimagnetic stirrer ments 


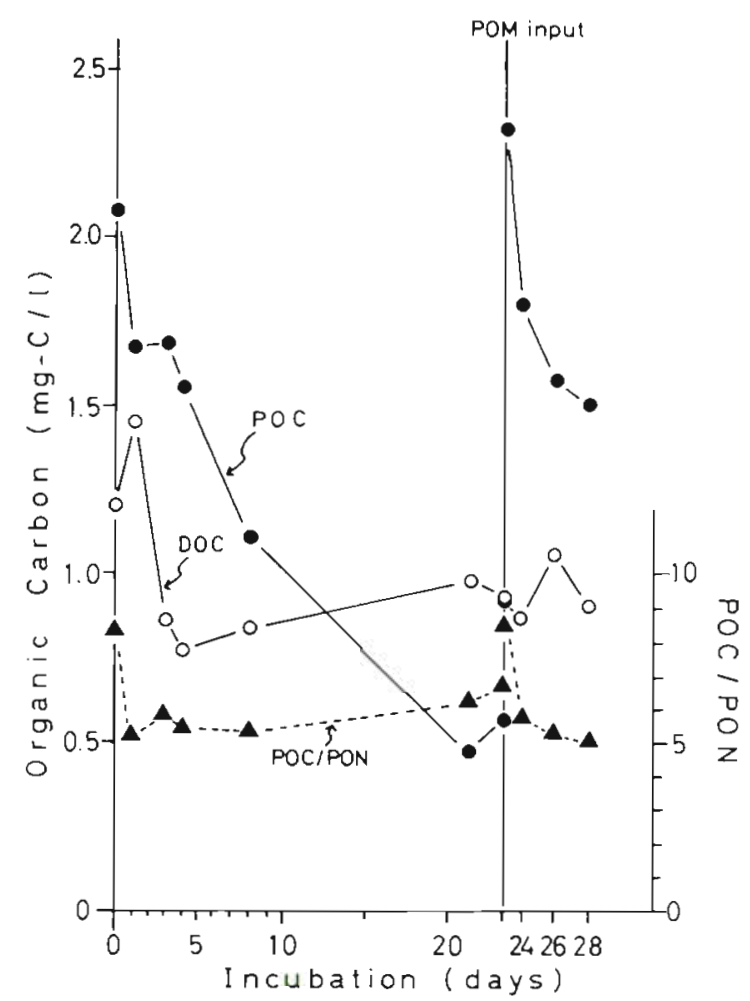

Fig. 2. Changes in concentrations of particulate organic carbon (POC) and dissolved organic carbon (DOC), and POC : particulate organic nitrogen (PON) ratio (POC : PON) during decomposition of Skeletonema costatum. On Day 23, fresh plankton material was added to the system

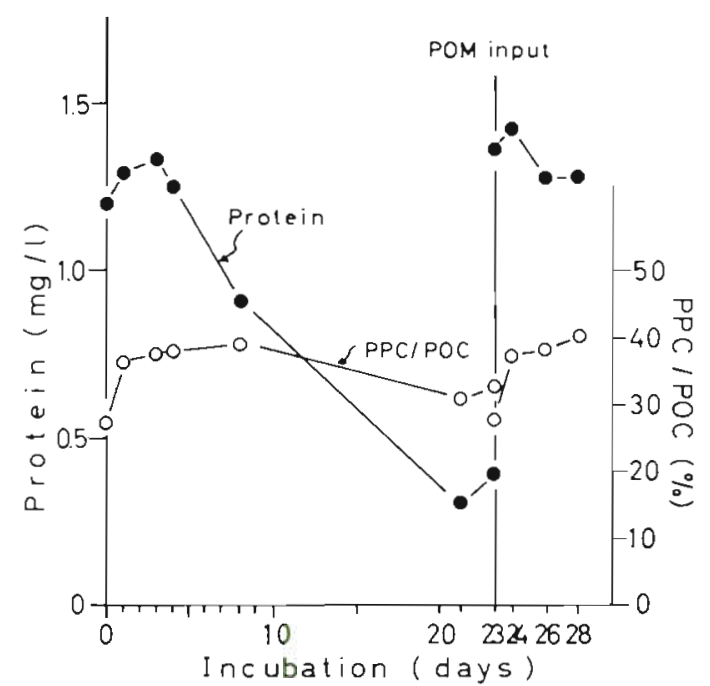

Fig. 3. Changes in particulate protein concentration and particulate protein carbon: particulate organic carbon ratio (PPC : POC) during decomposition of Skeletonema costatum. On Day 23, fresh plankton material was added to the system

not increase on the first day, but decreased more quickly than POC (Fig. 4). The concentration of particulate protein decreased parallel to that of $\mathrm{POC}$, and the proportion of protein in POM (PPC: POC) remained almost constant until Day 20 (Fig. 5).

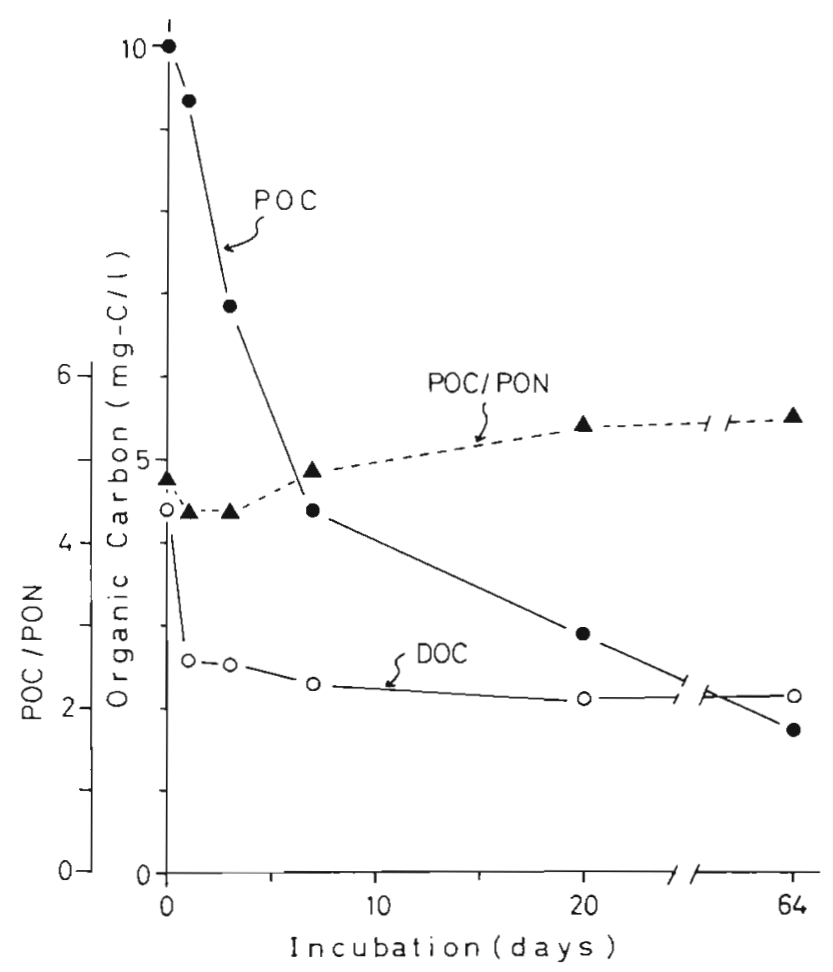

Fig. 4. Changes in concentrations of particulate organic carbon (POC) and dissolved organic carbon (DOC), and POC : particulate organic nitrogen (PON) ratio (POC : PON) during decomposition of Tigriopus japonicus

\section{DISCUSSION}

In previous reports (e.g. Otsuki and Hanya, 1972; Miyoshi, 1976), an extremely high concentration of planktonic organic material was used for experiments, far above the normal in situ level. In the present experiments, a relatively low concentration of planktonic organic matter was used. The initial concentrations of organic matter (as POC) of $2 \mathrm{mg} \mathrm{Cl}^{-1}$ in the phytoplankton experiment, and of $10 \mathrm{mg} \mathrm{Cl}^{-1}$ in the zooplankton experiment are equivalent to some 'red tide' conditions and to the tidal pool environment, respectively, which can often be observed in the natural environment.

We carried out 4 decomposition experiments using Skeletonema costatum. The initial concentration of planktonic organic matter ranged from $300 \mu \mathrm{g} \mathrm{Cl}^{-1}$ to $4 \mathrm{mg} \mathrm{C} \mathrm{l}^{-1}$. The results showed that the percent decrease of organic carbon in 1 wk was $37 \pm 5 \%$ of the initial concentration. Since the variability of the pattern of POC decrease was held within a relatively narrow range, we can say that our result is representative for such laboratory conditions.

In the present study, about $25 \%$ and more than $30 \%$ of the POC remained after Day 20 upon decomposition 


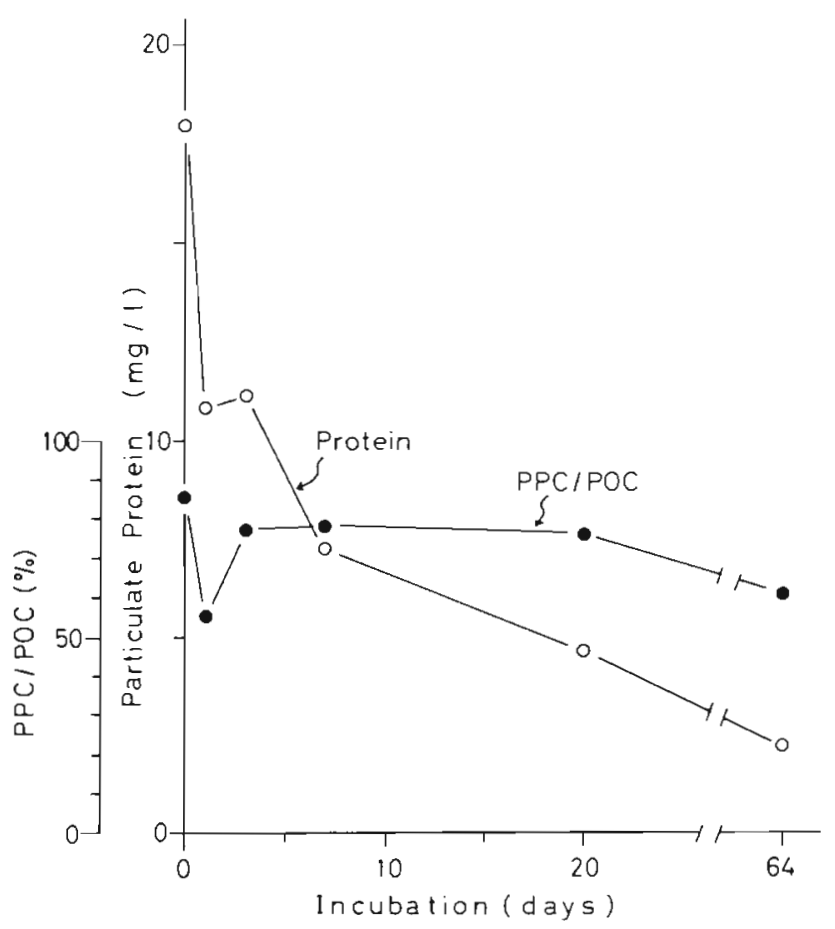

Fig. 5. Changes in particulate protein concentration and particulate protein carbon: particulate organic carbon ratio (PPC : POC) during decomposition of Tigriopus japonicus

of Skeletonema costatum and Tigriopus japonicus, respectively (Fig. 2 and 4). In a decomposition experiment using Chlorella sp. (Fukami et al., 1981), however, more than $90 \%$ of the POC in the plankton cell was decomposed by Day 20 . These results indicate that the former 2 organisms have more refractory substances than Chlorella, in particular the silicic theca of the diatom and the chitinous exoskeleton of the copepod.

Previous reports (Otsuki and Hanya, 1972; Fukami et al., 1981) showed that DOC was produced against a decrease of POC during phytoplankton decomposition. In the present study, in phytoplankton samples, the concentration of DOC increased on the first day, while POC rapidly decreased (Fig. 2). During decomposition of zooplankton, on the other hand, the POC decrease was not so sharp on the first day, and the DOC concentration did not increase but decreased more rapidly than POC (Fig. 4). These results suggest that the zooplankton body is more resistant to microbial attack than phytoplankton cells, presumably due to the rigid chitinous exoskeleton and because microorganisms, at first, utilized the labile DOC in the ambient seawater.

DOC concentration remained at an almost constant level after the first few days, both during phyto-and zooplankton decomposition, although the amount of POC decreased steadily throughout the decomposition process (Fig. 2 and 4). This suggests that organic mat- ter derived from the degraded plankton did not accumulate in the dissolved form (DOC) but was decomposed to $\mathrm{CO}_{2}$ very quickly.

The POC: PON ratio always decreased in the first few days (Fig. 2 and 4). Previous reports (Omori, 1969; Banse, 1974; Fukami et al., 1981) indicate that the C: $N$ ratio of phytoplankton is about 6 to 7 , that of zooplankton around 5, and that of some species of bacteria below 4 . This implies that the $\mathrm{C}: \mathrm{N}$ ratio of bacterial cells is significantly lower than that of the plankton; hence the decrease in the POC: PON ratio in degraded plankton detritus was attributed to an increase in bacterial organic matter (Fukami et al., 1981). Harrison and Mann (1975) reported that bacteria increased the nitrogen content of detrital eelgrass leaves, and during incubation the $C: N$ ratio of detritus decreased from over $20: 1$ to as low as $11: 1$. Newell (1965) also showed that the nitrogen content of the fecal pellet increased because of bacterial growth. In the present experiment using Skeletonema costatum, the concentration of particulate protein increased in contrast to the decrease of POC (Fig. 3). These results strongly suggest that during plankton decomposition more POC is mineralized than PON, and that PON is transformed into bacterial cells to a greater extent than POC. Dissolved inorganic and/or organic nitrogen are also utilized for producing bacterial cell materials. All of this would result in an increase in the protein content of detrital organic matter and a decrease in the POC : PON ratio during the early stages of decomposition, in spite of the fact that the amount of organic carbon decreased. Previous findings that dissolved organic carbon is transformed into detrital carbon by attached microflora (Paerl, 1974, 1978) also support our suggestion.

From the results of our experiments, we conclude that detritus, especially when derived from phytoplankton, becomes 'nitrogen-rich' during the early stages of decomposition because of the growth of bacteria on the detritus.

Acknowledgements. We thank Dr. W. J. Lee, National Fisheries University of Pusan, Korea, for help in collecting zooplankton samples. We also thank Mrs. Kazuko Fukami for helping with the DOC analysis.

\section{LITERATURE CITED}

Banse, K. (1974). On the interpretation of data for the carbonto-nitrogen ratio of phytoplankton. Limnol. Oceanogr. 19: $695-699$

Fenchel, T (1980). Suspension teeding in ciliated protozod: feeding rates and their ecological significance. Microbiol Ecol. 6: 13-25

Fenchel, T (1982). Ecology of heterotrophic microflagellates. II. Bioenergetics and growth. Mar. Ecol. Prog. Ser. 8: 225-231 
Fukami, K., Simidu, U., Taga, N. (1981). Fluctuation of the communities of heterotrophic bacteria during the decomposition process of phytoplankton. J. exp. mar. Biol. Ecol. 55: $171-184$

Fukami, K., Simidu, U, Taga, N. (1983). Change in a bacterial population during the process of degradation of a phytoplankton bloom in a brackish lake. Mar. Biol. 76: 253-255

Fukami, K., Simidu, U., Taga, N. (1985). Microbial decomposition of phyto- and zooplankton in seawater. II. Changes in the bacterial community. Mar. Ecol. Prog. Ser. 21: 7-13

Grill, E. V., Richards, F. A. (1964). Nutrient regeneration from phytoplankton decomposing in seawater. J. mar. Res. 22: $51-69$

Harding, G. C. (1973). Decomposition of marine copepods. Limnol. Oceanogr. 18: 670-673

Harrison, P. G., Mann, K. H. (1975). Detritus formation from eelgrass (Zostera marina L.): the relative effects of fragmentation, leaching, and decay. Limnol. Oceanogr. 20: 924-934

Iwamura, T., Nagai, H., Ichimura, S. (1970). Improved methods for determining contents of chlorophyll, protein, ribonucleic acid, and deoxyribonucleic acid in planktonic populations. Int. Revue ges. Hydrobiol. 55: 131-147

Kogure, K., Simidu, U., Taga, N. (1979). Effect of Skeletonema costatum (Grev.) Cleve on the growth of marine bacteria J. exp. mar. Biol. Ecol. 36: 201-216

Lowry, O. H., Rosebrough, N. J., Farr, A. L., Randall, R. J. (1951). Protein measurement with the Folin phenol reagent. J. biol. Chem. 193: 265-275

Miyoshi, H. (1976). Decomposition of marine plankton under laboratory conditions. Bull. Japan. Soc. scient. Fish. 42: 1205-1211

Newell, R. (1965). The role of detritus in the nutrition of two marine deposit feeders, the prosobranch Hydrobia ulvae and the bivalve Macoma balthica. Proc. zool. Soc. Lond. 144: $25-45$

Omori, M. (1969). Weight and chemical composition of some important oceanic zooplankton in the North Pacific Ocean. Mar. Biol. 3: 4-10

Otsuki, A., Hanya, T. (1972). Production of dissolved organic matter from dead green algal cells. I. Aerobic microbial decomposition. Limnol. Oceanogr. 17: 248-257

Paerl, H. W. (1974). Bacterial uptake of dissolved organic matter in relation to detrital aggregation in marine and freshwater systems. Limnol. Oceanogr. 19: 966-972

Paerl, H. W. (1978). Microbial organic carbon recovery in aquatic ecosystems. Limnol. Oceanogr. 23: 927-935

This paper was submitted to the editor; it was accepted for printing on August 29, 1984 